appeared earliest, as previously reported, ${ }^{45}$ and before day 11 of illness, coincident with the appearance of activated lymphocytes. Antienvelope protein antibodies, p41, and gp120/160 (data not shown; Gerald Robey) were first detected faintly at day 16 , coincident with clinical improvement.

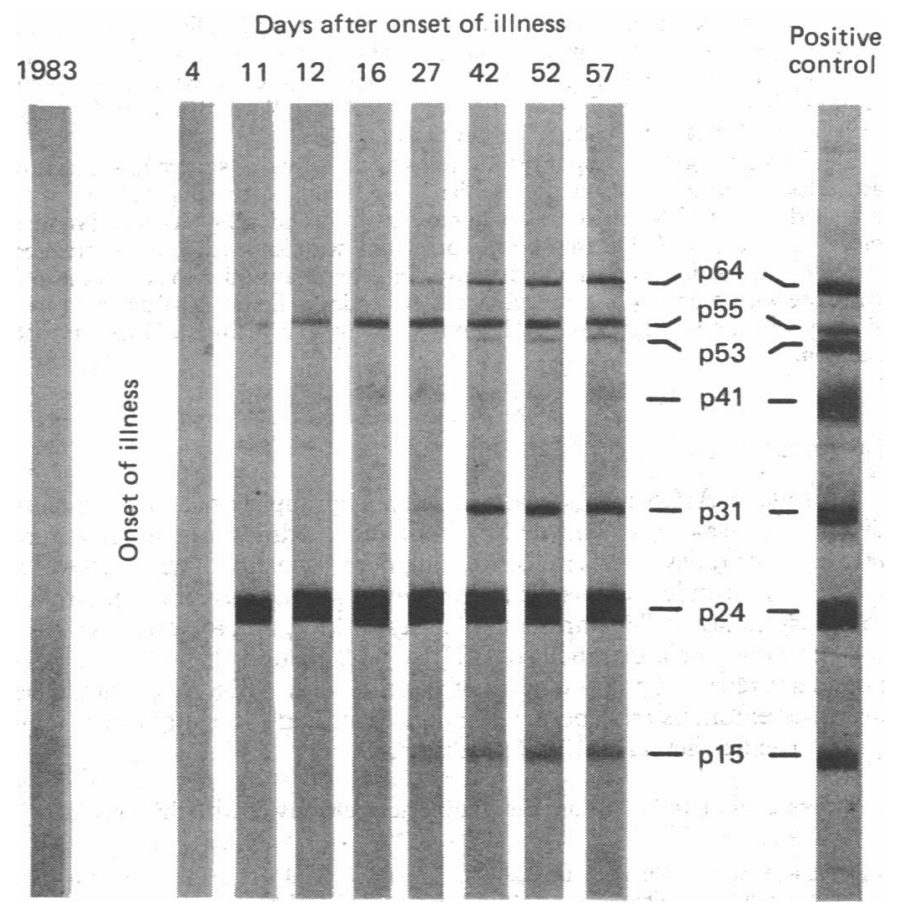

Appearance of antibody to HIV, as shown by Western blot analysis, in patient with acute febrile encephalopathy (days 2-15) and residual lymphadenopathy. Western blot analysis was performed with HIV grown in $\mathrm{H} 9$ cell lines. Serum obtained during the illness was analysed in the same tray using an avidin-biotinperoxidase technique to show antibody attachment to HIV polypeptides. ${ }^{4}$ Serum from 1983 was available from a previous study.

Antibodies against other antigens (p15, p31, p53, p64) appeared before day 27 , coincident with the development of persistent generalised lymphadenopathy. Thus severe symptoms including an illness similar to mononucleosis, encephalopathy, and persistent generalised lymphadenopathy may occur as a consequence of primary HIV infection. Whether this profile development of antibody to HIV is typical of other seroconversions remains unknown.

1 Anonymous. Needlestick transmission of HTLV-III from a patient infected in Africa [Editorial]. Lancet 1984;ii:1376-7.

2 Cooper DA, Gold J, Maclean P, et al. Acute AIDS retrovirus infection: definition of a clinical illness associated with seroconversion. Lancet 1985;i:537-40.

3 Carne CA, Tedder RS, Smith A, et al. Acute encephalopathy coincident with seroconversion for anti-HTLV-III. Lancet 1985;ii: 1206-8.

4 Biggar RJ, Melbye M, Ebbesen P, et al. Variation in human T lymphotropic virus III (HTLV-III) antibodies in homosexual men: decline before onset of illness related to acquired immun deficiency disease syndrome (AIDS). Br Med f 1985;291:997-8.

5 Esteban JI, Shih JWK, Tai CC, Bodner AJ, Kay JWD, Alter HJ. Importance of Western blo analysis in predicting infectivity of anti-HTLV-III/LAV positive blood. Lancet 1985;ii:1084-6.

(Accepted 11 August 1986)

Environmental Epidemiology Branch, National Cancer Institute, Bethesda, Maryland, USA

ROBERT J BIGGAR, MD, senior investigator

Virus Research Centre, Kenya Medical Research Institute, Nairobi, Kenya BRUCE K JOHNSON, PHD, virologist

Nairobi Hospital, Nairobi, Kenya

SHEM S MUSOKE, MB, CHB, private practitioner

JOHN B MASEMBE, $\mathrm{MB}, \mathrm{CHB}$, private practitioner

DAVID M SILVERSTEIN, MD, private practitioner

MAJID M WARSHOW, MB, CHB, private practitioner

Biotech Research Inc, Rockville, Maryland, USA

STEVEN ALEXANDER, PHD, immunologist

Correspondence to: Dr R J Biggar, Landow Building 3C19, National Institutes of Health, Bethesda, Maryland 20205, USA.

\section{Transient ascites in progressive systemic sclerosis}

The differential diagnosis for ascites of sudden onset is extensive. ${ }^{1}$ We report transient ascites in two patients with progressive systemic sclerosis.

\section{Case 1}

A 64 year old woman had a 17 year history of progressive systemic sclerosis, manifested by Raynaud's syndrome, sclerodactyly, calcinosis, telangiectasia, and dysphagia. She developed tense ascites over three days, with oedema to midabdomen. No other abnormal clinical findings were present. Treatment was with penicillamine $300 \mathrm{mg}$, nifedipine retard $40 \mathrm{mg}$, and inositol nicotinate $2 \mathrm{~g}$ daily. Haemoglobin and electrolyte concentrations, erythrocyte sedimentation rate, and results of liver function tests (including prothrombin time and albumin concentration) were normal. $\alpha$ Fetoprotein and carcinoembryonic antigen were not detected. The anticentromere antibody titre was positive. Ascitic fluid contained $12 \mathrm{~g}$ protein $/$, and the cell count was $80 \times 10^{6}$ cells (predominantly lymphocytes)/l. Gram staining, culture, and cytological examination yielded negative results. Urine did not contain any protein. A chest $x$ ray film, echocardiogram, isotope liver scan, and hepatic phlebogram were normal. Ultrasonography and computed tomography of the abdomen confirmed ascites; findings were otherwise normal. Barium studies showed abnormalities of the oesophagus, stomach, small bowel, and proximal colon consistent with progressive systemic sclerosis. Endoscopic biopsy of the oesophagus, stomach, and jejunum did not show any evidence of malignancy.

The oedema and ascites resolved with diuretic treatment and had not recurred 18 months later (July 1986), when she was no longer taking diuretics, though the other drugs were maintained at the same dose.

\section{Case 2}

A 59 year old woman developed ascites over six weeks. She had facial telangiectasia and sclerodactyly. At laparotomy 6 litres of straw coloured fluid was removed. The liver was normal, and biopsy was performed. A "fine white mesh like appearance" of the small bowel was noted at operation. Haemoglobin and electrolyte concentrations, erythrocyte sedimentation rate, and results of liver function tests were normal. The anticentromere antibody titre was positive. Carcinoembryonic antigen was not detected, and the $\alpha$ fetoprotein concentration was $204 \mathrm{kU} / 1$ (normal $<15 \mathrm{kU} / \mathrm{l}$ ). Results of histological examination of the liver biopsy specimen, 24 hour urinary protein excretion, and a chest $x$ ray film were normal. Radiography of the hands showed calcinosis circumscripta. Barium studies showed diminished oesophageal peristalsis, dilatation of the small bowel from mid-jejunum to ileum, and normal large bowel. Ultrasonography of the abdomen showed patent hepatic veins and no abnormality of the liver. $\alpha$ Fetoprotein concentration at three months and subsequently was $<5 \mathrm{kU} / \mathrm{l}$.

Nineteen months later the ascites had not recurred and she was otherwise well; she was not receiving any treatment.

\section{Comment}

These patients with progressive systemic sclerosis presented with ascites of recent onset. Extensive investigation excluded recognised causes of ascites, including liver disease, the Budd-Chiari syndrome, right heart failure, constrictive pericarditis, the nephrotic syndrome, and occult malignancy. Only one other case of otherwise unexplained ascites has been reported in a patient with progressive systemic sclerosis, who was positive for hepatitis B surface antigen and had exudative ascites with unexplained bony erosions. ${ }^{2}$ No follow up information was given, and it is difficult to exclude recognised causes of ascites. In other series of patients with progressive systemic sclerosis ascites has been reported only in association with hepatic fibrosis ${ }^{3}$ and cirrhosis. ${ }^{4}$

Pleural and pericardial fibrosis and effusions are well recognised in progressive systemic sclerosis and have been shown at necropsy to be associated with serositis. ${ }^{3-5}$ One detailed necropsy study, however, showed that peritonitis and peritoneal adhesions were no more common in 57 patients with progressive systemic sclerosis than in controls. ${ }^{5}$ Abnormalities of the bowel wall are well recognised in progressive systemic sclerosis and were documented in our patients; low grade peritoneal inflammation might well result in ascites in such patients. As the ascites resolved rapidly the causative factor was presumably transient. We suggest that the differential diagnosis of ascites in progressive systemic sclerosis should include this apparently benign condition, which responds to medical management.

We thank Mr D J Pinto, consultant surgeon, Tyrone County Hospital, Omagh, County Tyrone, for referring case 2 and for permission to report his findings at laparotomy.

1 Beeson PB, McDermott W, Wyngaarden JB, eds. Textbook of medicine. 15th ed. Philadelphia: WB Saunders, 1979:1592-3.

2 Quagliata F, Sebes J, Pinstein ML, Schmidt LW. Long bone erosions and ascites in systemic sclerosis. F Rheumatol 1982;9:641-4. 
3 Bartholomew LG, Cain JC, Winkelmann RK, Baggenstoss AH. Chronic disease of the liver associated with systemic scleroderma. Am $\mathcal{F}$ Dig Dis 1964;9:43-55.

4 Tuffanelli D, Winkelmann RK. Systemic scleroderma: a clinical study of 727 cases. Arch Dermatol $1961 ; 84: 359-71$

5 D'Angelo WA, Fries JF, Masi AT, Shulman LE. Pathologic observations in systemic sclerosis (scleroderma). Am F Med 1969;46:428-40.

(Accepted 4 August 1986

\section{Royal Victoria Hospital, Belfast BT12 6BA}

J J A MCALEER, MB, MRCP, registrar, internal medicine

S R CUNNINGHAM, MB, MRCP, senior house officer, general medicine

W DICKEY, $\mathrm{MB}, \mathrm{BCH}$, senior house officer, general medicine

D BURROWS, MD, FRCP, consultant dermatologist

M E CALLENDER, MB, MRCP, consultant physician

\section{Attitudes to and knowledge about the acquired immune deficiency syndrome: lack of a correlation}

The acquired immune deficiency syndrome (AIDS) is a controversial disease about which there is much public ignorance and confusion. A recent government advertising campaign attempted to inform the general public about the disease's aetiology, epidemiology, and prognosis. Such advertising presumes that the provision of factual information will modify attitudes towards the disease. As homosexuals are a stigmatised group within society, however, it is possible that attitudes to the treatment of AIDS are not related to specific knowledge about the disease but are instead a consequence of general attitudes to homosexuality. In this study we examined attitudes among preclinical medical students, whom we may regard as a surrogate for "the educated layman" in that they have a good knowledge of biological principles and are likely to have a high awareness of and interest in issues about AIDS but have not received any specific clinical training about or exposure to the disease and its treatment. If factual information could be effective in modifying attitudes it should be evident in this group.

\section{Method and results}

Anonymous questionnaires were distributed at lectures to medical students in their first and second preclinical years at University College London in February 1986. Attitudes were assessed on five point scales ( $1=$ strongly disagree; $5=$ strongly agree). Questions concerned attitudes to homosexuality (18 items modified from previous studies ${ }^{12}$ ), attitudes to AIDS (eight questions; see table) knowledge of AIDS (13 questions, with a total of 36 subitems), religious and political views, and whether the student was homosexual.
Altogether 143 questionnaires were returned, representing $69 \cdot 8 \%$ of those w distributed and $55 \cdot 0 \%$ of the students. On the scale for knowledge of AIDS (36 items) the subjects had a mean score of $21 \cdot 5$ correct (SD 6.0, range 1-33). The Spearman-Brown split half reliability, which is calculated from the correlation of $Q$ scores on odd and even numbered items, ${ }^{3}$ was 0.852 . The scale for attitude to $C$ homosexuality (18 items) had a possible range of scores of $18-90$, with an actual $\widehat{T}$ mean score of $61 \cdot 4$ (SD 15.7, range 18-89) and reliability of $0 \cdot 950$. High scores indicated a positive attitude towards homosexuals and homosexuality. Religion was scored on a seven point scale ${ }^{1} 1$ indicating atheists and 7 indicating Christians $\mathbb{D}_{\mathbb{D}}$ who attended church one or more times a week; non-Christians were excluded $\$$ from subanalyses when appropriate. Political views were scored on a five point $T$ scale: $1=$ National Front; 2 =Conservative; 3 =Liberal, Social Democratic party, or Alliance; $4=$ Labour; and $5=$ Communist or far left.

The table shows the responses of subjects to the eight statements showing $\stackrel{\vec{\rho}}{\vec{S}}$ attitudes to AIDS and the Pearsonian correlation of those responses with $-\overrightarrow{0}$ knowledge of AIDS, attitudes to homosexuality, and religious and political views. Attitudes to AIDS showed no correlation with knowledge but correlated strongly with attitudes to homosexuality. In general attitudes to AIDS did not $\frac{\Phi}{\vec{T}}$ correlate with religious or political views. Attitudes to homosexuality correlated $\mathbb{\mathbb { D }}$ slightly with knowledge about AIDS but strongly with politics and less so with religion.

\section{Comment}

Attitudes to AIDS and its treatment among a group of preclinical students did not correlate with knowledge about the condition but instead were related to attitudes in general concerning homosexuality. The absence of a i relation of attitudes to specific knowledge is a not uncommon finding in $\underset{\omega}{\omega}$ social psychology. ${ }^{4}$ The implication for health education is clear: if we wish $\delta$ to reduce the "prejudice about AIDS [that] still abound[s]"s and to increase of public awareness of the problems of patients with AIDS there should be ? increased emphasis on general education about homosexuality rather than $\vec{N}$ on the specific, factual details of the disease.

We are grateful to Dr A Furnham for his help and advice with this project.

1 Larsen K, Reed M, Hoffman S. Attitudes of heterosexuals toward homosexuality-a Likert-type scale and construct validity. Fournal of Sex Research 1980;16:245-57.

McManus IC. Medical students: origins, selection, attitudes and culture. London: University of London, 1985. (MD thesis.)

Ghiselli EE, Campbell JP, Zedeck S. Measurement theory for the behavioral sciences. San Francisco: WH Freeman, 1981:252.

Nunnally J. Popular conceptions of mental health: their development and change. New York: Holt, $\vec{\omega}$ Rinehart and Winston, 1961 .

Pinching AJ. Medicine and the media. BrMed f 1986;292:1327.

(Accepted 6 August 1986)

Department of Psychology, University College London, London WC1

A D MORTON, BSC, medical student

I C MCMANUS, MD, PHD, lecturer in psychology applied to medicine

Correspondence to: Dr McManus.

Relation of eight attitudes to AIDS and its treatment with measures of knowledge about AIDS, attitudes to homosexuality, and measures of religious and political views, and inter-relation of the measures

\begin{tabular}{|c|c|c|c|c|c|c|c|c|c|}
\hline & & & & & & \multicolumn{4}{|c|}{ Correlations } \\
\hline & \multicolumn{5}{|c|}{ No (\%) of subjects scoringt: } & \multirow{2}{*}{$\begin{array}{l}\text { Scale for } \\
\text { knowledge of } \\
\text { AIDS }\end{array}$} & \multirow{2}{*}{$\begin{array}{l}\text { Scale for } \\
\text { attitudes to } \\
\text { homosexuality }\end{array}$} & \multirow[b]{2}{*}{ Religion } & \multirow[b]{2}{*}{ Politics } \\
\hline & 1 & 2 & 3 & 4 & 5 & & & & \\
\hline & \multicolumn{9}{|c|}{ Relation of attitudes to AIDS with other measures } \\
\hline $\begin{array}{l}\text { There is likely to be a cure for AIDS in the next } \\
\text { five years } \\
\text { AIDS is likely to become a relatively common }\end{array}$ & $24(17)$ & $28(20)$ & $58(41)$ & $25(18)$ & $7(5)$ & $-0 \cdot 141$ & 0.087 & 0.012 & -0.009 \\
\hline $\begin{array}{l}\text { heteroserual disease } \\
\text { The only way to control AIDS is to make all homosexual }\end{array}$ & $10(7)$ & $27(19)$ & $43(30)$ & $43(30)$ & $19(13)$ & -0.043 & 0.038 & -0.003 & 0.038 \\
\hline $\begin{array}{l}\text { activity illegal } \\
\text { AIDS patients present such a threat to society that }\end{array}$ & $87(62)$ & $30(21)$ & $10(7)$ & $9(6)$ & $4(3)$ & $-0 \cdot 110$ & $-0 \cdot 493^{\star \star \star}$ & 0.060 & $-0 \cdot 305^{\star \star \star}$ \\
\hline $\begin{array}{l}\text { they should be compulsorily detained in hospital as } \\
\text { soon as they are dingnosed }\end{array}$ & $36(25)$ & $49(34)$ & $19(13)$ & $23(16)$ & $16(11)$ & -0.033 & $-0 \cdot 444^{\star \star \star}$ & 0.056 & $-0 \cdot 142$ \\
\hline $\begin{array}{l}\text { Patients who have contracted AIDS through } \\
\text { homosexual activity do not deserve medical care } \\
\text { Fear of infection with AIDS will reduce the quality of }\end{array}$ & $116(81)$ & $15(11)$ & $3(2)$ & $3(2)$ & $6(4)$ & -0.012 & $-0 \cdot 398^{\star \star \star}$ & $-0 \cdot 028$ & -0.057 \\
\hline $\begin{array}{l}\text { care given to homosexual patients } \\
\text { Describing AIDS as the "gay plague" is an }\end{array}$ & $10(7)$ & $19(13)$ & $20(14)$ & $67(47)$ & $27(19)$ & -0.031 & $-0 \cdot 211^{\star}$ & $0 \cdot 141$ & 0.002 \\
\hline $\begin{array}{l}\text { overemotional response to a serious illness } \\
\text { More medical research funds should be given to }\end{array}$ & $6(4)$ & $23(16)$ & $23(16)$ & $37(26)$ & $54(38)$ & -0.009 & $0.511^{\star \star \star}$ & $-0 \cdot 159$ & $0 \cdot 209^{\star}$ \\
\hline developing a vaccine against AIDS & $3(2)$ & $6(4)$ & $19(13)$ & $41(29)$ & $74(52)$ & -0.067 & $0 \cdot 169$ & $-0 \cdot 197^{\star}$ & $-0 \cdot 105$ \\
\hline $\begin{array}{l}\text { Scale for knowlodge of AIDS } \\
\text { Scale for attitudes to homosexuality } \\
\text { Religion } \\
\text { Politics }\end{array}$ & & & & & Inter-relatic & $\begin{array}{l}\text { fother measures } \\
\qquad \begin{array}{l}0.172 \\
-0.256^{\star \star \star} \\
0.132\end{array}\end{array}$ & $\begin{array}{l}0 \cdot 172 \\
-0 \cdot 287^{\star \star \star} \\
0 \cdot 451^{\star \star \star}\end{array}$ & $\begin{array}{l}-0 \cdot 256^{\star \star \star} \\
-0 \cdot 287^{\star \star \star} \\
-0 \cdot 188^{\star}\end{array}$ & $\begin{array}{l}0 \cdot 132 \\
0 \cdot 451^{\star \star \star} \\
-0 \cdot 188^{\star}\end{array}$ \\
\hline
\end{tabular}

